\title{
PENGARUH FUNDAMENTAL EKONOMI DAN PERUSAHAAN TERHADAP HARGA OBLIGASI PERUSAHAAN MANUFAKTUR YANG TERDAFTAR DI BURSA EFEK INDONESIA
}

\author{
Dijan Mardiati ${ }^{1}$ \\ 1) dosen universitas pamulang, email : diyanm@gmail.com
}

\section{ARTICLES}

INFORMATION

ABSTRACT

\section{JURNAL SEKURITAS \\ (Saham, Ekonomi, Keuangan dan Investasi ) \\ Vol.1, No.4, Juni 2018 \\ Halaman : 106 - 131 \\ (c) LPPM \& Prodi Manajemen \\ UNIVERSITAS PAMULANG \\ ISSN (online) : 2581-2777 \\ ISSN (print) : :2581-2696}

\section{Keyword :}

Economic and company fundamental, and bond price of emitten

JEL. classification :

C33, G20, G23, N65

\section{Contact Author :}

PRODI MANAJEMEN UNPAM

JL.Surya Kencana No.1 Pamulang

Tangerang Selatan - Banten

Telp. (021) 7412566, Fax (021) 7412491 Email :

jurnalfinance.unpam@gmail.com
Penelitian ini bertujuan untuk mengetahui pengaruh Fundamental Ekonomi dan Perusahaan Terhadap Harga Obligasi Emiten Manufaktur Yang Terdaftar di Bursa Indonesia secara parsial maupun simultan pada PT. Bursa Efek Indonesia.

Dengan menggunakan metode analisis deskriptif kuantitatif, dan random sampel sebanyak 69 data time series serta pengolahan statistik menggunakan SPSS, hasil penelitian menunjukkan bahwa : 1) Tingkat suku bunga berpengaruh terhadap Harga Obligasi Perusahaan manufaktur yang terdaftar di Bursa Efek Indonesia 2) Inflasi berpengaruh signifikan terhadap harga obligasi Perusahaan manufaktur yang terdaftar di Bursa Efek Indonesia. 3) Debt to Equity Ratio berpengaruh signifikan terhadap harga obligasi perusahaan manufaktur yang terdaftar di Bursa Efek Indonesia 4) Return to Equity berpengaruh signifikan terhadap harga obligasi perusahaan manufaktur yang terdaftar di Bursa Efek Indonesia 5) Return to Investment berpengaruh signifikan terhadap harga obligasi perusahaan manufaktur yang terdaftar di Bursa Efek Indonesia 6) Tingkat suku bunga, inflasi, Debt to Equity Ratio, Return on Equity dan Rweturn on Investment secara simultan berpengaruh signifikan terhadap Harga Obligasi Perusahaan manufaktur yang terdaftar di Bursa Efek Indonesia sebesar 36,1\%, sisanya 63,9 $\%$ dipengaruhi oleh variabel lain yang tidak diteliti.

This study aimed to analyze the influence of economic and company fundamental on the bond price of emitten partially or simultaneously at the Indonesia Stock Exchange. This research was conducted by using descriptive and quantitative analysis methods. The random sampling technique using a sample of 69 time series datas and analysis tools using SPSS. The results showed that: 1) The interest rate affected the bond price of the company registered in The Indonesia Stock Exchange. 2) The Inflation rate affected the bond price of the company registered in The Indonesia Stock Exchange. 3) The Debt of Equity affected the bond price of the company registered in The Indonesia Stock Exchange. 4) The Return of Equity affected the bond price of the company registered in The Indonesia Stock Exchange. 5) The return of Investment affected the bond price of the company registered in The Indonesia Stock Exchange. 6) The interest rate, Debt to Equity Ratio, Return On Equity, and Return on Investment affected the bond price of the company registered in The Indonesia Stock Exchange by $36,1 \%$, the remaining $63,9 \%$ is influenced by other variables not examined. 


\section{A. Pendahuluan}

Menurut data laporan Bursa Efek Indonesia selama tahun 2006 - 2008, perkembangan permintaan obligasi menunjukkan peningkatan yang cukup berarti, yaitu sebesar $55 \%$ pertahun. Hal ini menunjukkan tingkat kepercayaan masyarakat yang semakin tinggi untuk berinvestasi melalui instrumen obligasi.

Ada beberapa keuntungan berinvestasi obligasi yaitu antara lain bagi emiten, bunga pinjaman yang harus dibayarkan lebih rendah daripada bunga pinjaman bank, sedangkan bagi investor, akan mendapatkan bunga yang lebih tinggi daripada bunga simpanan bank. Selain itu untuk obligasi juga bisa digunakan untuk proyek dengan jangka waktu pendek, dimana perusahaan bisa memperoleh dana secara langsung tanpa melalui termin-termin pembayaran. Disamping itu pemilik perusahaan masih bisa leluasa mengendalikan perusahaan, karena obligasi tidak mempengaruhi kepemilikan perusahaaan. Sedangkan apabila jumlah obligasi telah habis dan permintaan investor masih besar, maka perusahaan boleh menerbitkan obligasi secara berseri / berkesinambungan.

Namun pertumbuhan permintaan obligasi ini tidak sebanding dengan peningkatan jumlah emiten. Pertumbuhan emiten obligasi rata-rata dari tahun 2008 - 2013 hanya $12 \%$ pertahun. Faktor penghambat pertumbuhan emiten lain adalah pertimbangan pihak investor terhadap suku bunga. Suku bunga merupakan salah satu indikator yang mempengaruhi suatu perusahaan menerbitkan obligase atau tidak. Suku bunga global sangat mempengaruhi tingkat suku bunga obligasi yang diterbitkan di dalam negeri. Kenaikan tingkat suku bunga akan menekan perusahaan untuk memberikan yield yang lebih tinggi agar obligasinya terjual di pasar.

Seiring dengan pemulihan perekonomian global, terdapat kemungkinan laju inflasi, kenaikan harga minyak dunia, kebijakan Bank Central Amerika Serikat, yang mana semua itu dapat mempengaruhi kebijakan Bank Indonesia. Resiko - resiko makroekonomi dan suku bunga inilah yang cukup menghambat pasar obligasi korporasi domestik, dimana apabila suku bunga acuan Bank Indonesia naik, berdampak pada kupon obligasi yang lebih tinggi. Hal inilah yang menyebabkan meningkatnya beban biaya emisi obligasi sehingga mengurangi minat emiten.

Pertumbuhan emiten di Indonesia, tidak terlepas pula dari faktor fundmental perusahaan penerbit obligasi tersebut. Faktor fundamental perusahaan itu antara lain adalah kinerja perusahaan yang dapat diukur melalui laporan keuangan perusahaan. Indikator kinerja perusahaan dapat diamati diantaranya melalui rasio leverage dan rasio profitabilitas. Rasio profitabilitas adalah kemampuan perusahaan memperoleh laba dalam hubungannya dengan penjualan, total aktiva maupun modal sendiri. Menurut Kamstra, dkk (2001) rasio profitabilitas yang diukur dengan ROI mempunyai pengaruh positif terhadap pertumbuhan laba. Karena rasio ini mewakili ukuran keberhasilan manajemen terhadap penggunaan hutang dan ekuitasnya untuk menghasilkan laba. Demikian juga dengan ROE, rasio ini mewakili ukuran keberhasilan manajemen dalam mengelola modal sendiri / ekuitasnya untuk menghasilkan laba. Semakin tinggi kinerja keuangan perusahaan emiten, maka semakin tinggi pula posisi tawar produk obligasinya

Rasio Leverage digunakan untuk mengukur tingkat penggunaan utang sebagai sumber pembiayaan perusahaan. Rasio leverage yang akan digunakan dalam penelitian ini adalah Debt to Equity Ratio. Bila nilai Debt to Equity Ratio meningkat menunjukkan 
bahwa perusahaan menggunakan leverage keuangan (hutang) yang meningkat juga. Semakin tinggi hutang maka resiko untuk gagal bayar pada perusahaan tersebut juga semakin besar. Semakin besar resiko gagal bayar maka permintaan akan obligasi akan menurun yangberdampak pada posisi tawar / harga obligasi yang menurun pula.

\section{B. Perumusan Masalah}

Berdasarkan latar belakang masalah tersebut, maka dapat dibuat perumusan masalah dalam penelitian ini sebagai berikut:

1. Apakah faktor fundamental ekonomi yaitu suku bunga berpengaruh terhadap harga obligasi perusahaan manufaktur yang terdaftar di Bursa Efek Indonesia ?

2. Apakah faktor fundamental ekonomi berupa inflasi berpengaruh terhadap harga obligasi perusahaan manufaktur yang terdaftar di Bursa Efek Indonesia ?

3. Apakah faktor fundamental perusahaan berupa debt to equity ratio berpengaruh terhadap harga obligasi perusahaan manufaktur yang terdaftar di Bursa Efek Indonesia?

4. Apakah faktor fundamental perusahaan berupa return on equity berpengaruh terhadap harga obligasi perusahaan manufaktur yang terdaftar di Bursa Efek Indonesia?

5. Apakah faktor fundamental perusahaan berupa return on investment berpengaruh terhadap harga obligasi perusahaan manufaktur yang terdaftar di Bursa Efek Indonesia?

6. Apakah faktor fundamental perusahaan berupa bunga, inflasi, debt to equity ratio, return on equity, dan return on investment berpengaruh secara simultan terhadap harga obligasi

perusahaan manufaktur yang terdaftar di Bursa Efek Indonesia?

\section{Tujuan Penelitian}

1. Mengetahui Suku bunga berpengaruh terhadap Harga Obligasi

2. Mengetahui Inflasi berpengaruh terhadap harga obligasi

3. Mengetahui pengaruh Debt to Equity Ratio (DER) terhadap Harga Obligasi

4. Mengetahui pengaruh Return on Equity (ROE) terhadap Harga Obligasi

5. Mengetahui pengaruh Return on Investment (ROI) terhadap Harga Obligasi

6. Mengetahui pengaruh suku bunga, inflasi, DER, ROE, dan ROI berpengaruh terhadap Harga Obligasi

\section{Landasan Teori}

\section{Manajemen}

Menurut James A. F. Stoner manajemen merupakan suatu proses perencanaan, pengorganisasian, kepemimpinan, dan pengendalian upaya dari anggota organisasi serta penggunaan semua sumber daya yang ada pada organisasi untuk mencapai tujuan organisasi yang telah ditetapkan sebelumnya.

Sondang P Siagian (2002:7) menyebutkan, manajemen adalah kemampuan dan keterampilan untuk memperoleh sesuatu hasil dalam rangka pencapaian tujuan melalui kegiatan-kegiatan orang lain.

\section{Manajemen Keuangan}

Menurut Harjito (2012; 2) Manajemen keuangan adalah segala aktifitas perusahaan yang berhubungan dengan bagaimana memperoleh dana, dan mengelola asset sesuai dengan tujuan perusahaan secara menyeluruh. Dengan kata lain, manajemen keuangan merupakan manajemen (pengelolaan) mengenai 
bagaimana memperoleh aktiva, mendanai aktiva dan mengelola aktiva untuk mencapai tujuan perusahaan. Jadi ada 3 fungsi utama dalam Manajemen Keuangan, yaitu

(1) Keputusan investasi (investment decision)

(2) Keputusan Pendanaan (financing decision)

(3) Keputusan pengelolaan asset (asset management decision)

Keputusan Investasi merupakan keputusan terhadap aktiva apa yang akan dikelola oleh perusahaan. Keputusan investasi merupakan keputusan yang paling penting diantara ketiga keputusan tersebut, karena keputusan ini berpengaruh secara langsung terhadap rentabilitas investasi dan aliran kas untuk waktu yang akan datang. Rentabilitas investasi (return on investment) merupakan kemampuan perusahaan memperoleh laba yang dihasilkan dari suatu investasi.

Keputusan pendanaan menyangkut beberapa hal, pertama, keputusan mengenai penetapan sumber dana yang diperlukan untuk membiayai investasi. Sumber dana tersebut bisa berupa hutang jangka pendek, hutang jangka panjang, atau modal sendiri.

\section{Teori tentang Obligasi}

Menurut Bursa Efek Indonesia, obligasi adalah surat utang jangka menengah panjang yang dapat dipindahtangankan yang berisi janji dari pihak yang menerbitkan untuk membayar imbalan berupa bunga pada periode tertentu dan melunasi pokok utang pada waktu yang telah ditentukan kepada pihak pembeli obligasi tersebut.

Sebagai efek yang bersifat utang, obligasi memiliki beberapa karakteristik sebagai berikut :

(1) Nilai Nominal (Face Value) adalah nilai pokok dari suatu obligasi yang akan diterima oleh pemegang obligasi pada saat obligasi jatuh tempo.

(2) Kupon (The Interest Rate) adalah nilai bunga yang diterima pemegang obligasi secara berkala (kelaziman pembayaran kupon obligasi adalah setiap 3 atau 6 bulanan), dinyatakan dalam annual prosentase.

(3) Jatuh Tempo (Maturity) adalah tanggal dimana pemegang obligasi akan mendapatkan pembayaran kembali pokok atau nilai nominal obligasi yang dimilikinya. Periode jatuh tempo obligasi bervariasi mulai dari 365 hari sampai dengan diatas 5 tahun.

(4) Penerbit / Emiten (Issuer)

Menurut Zubir (2012;6), besarnya resiko dalam investasi obligasi tergantung pada jenis dan emiten obligasi tersebut. Unsecured Bond beresiko lebih besar daripada secured bond, obligasi perusahaan lebih beresiko daripada obligasi pemerintah. Potensi resiko yang dihadapi investor dalam obligasi adalah sebagai berikut

(1) Resiko tingkat bunga (interest rate risk). Bila tingkat bunga pasar naik, maka harga obligasi akan turun. Bila obligasi tersebut dijual dalam kondisi tingkat bunga tinggi, maka investor akan rugi. Oleh karenanya selam tingkat bunga tinggi, investor akan menahan untuk tidak menjual obligasi tersebut. Makin panjang jangka waktu jatuh tempo obligasi, maka makin besar resiko tingkat bunga yang dihadapi investor. Untuk meminimumkan resiko tingkat bunga, obligasi tersebut obligasi tersebut dipegang sampai jatuh tempo. 
(2) Resiko gagal bayar (default risk). Yaitu bila emiten tidak mampu membayar pinjaman pokoknya pada saat jatuh tempo. Resiko gagal bayar bergantung pada kesehatan keuangan perusahaan yang tercermin pada laporan rugi laba dan neracanya. Untuk melindungi investor, obligasi perusahaan dinyatakan peringkatnya oleh lembaga pemeringkat independent sebagai cerminan dari analisis kemampuan perusahaan membayar kewajibannya. Makin sehat perusahaan, makin tinggi peringkatnya.

(3) Call risk, yaitu resiko yang timbul karena obligasi tersebut dibeli kembali oleh issuer pada harga tertentu sebelum jatuh tempo yang menguntungkan issuer. Issuer akan membeli kembali obligasi tersebut bila tingkat bunga berada di bawah coupon rate. Kemudian issuer akan menerbitkan obligasi baru dengan kupon yang lebih rendah. Oleh karena itu obligasi yang mengandung call option (callable bond) dijual lebih rendah daripada obligasi non-callable yang setingkat.

(4) Purchasing power risk, yaitu resiko yang disebabkan oleh inflasi yang akan menggerus return obligasi tersebut. Kupon yang diterima investor adalah tetap, sementara daya belinya akan turun dengan adanya inflasi. Untuk menghadapi inflasi tersebut, investor akan memilih obligasi yang memberikan return yang lebih tinggi daripada tingkat inflasi..

(5) Reinvestment risk yaitu resiko atas return investasi kupon obligasi. Semua kupon menghadapi resiko reinvestasi tersebut. Kupon yang diterima investor diinvestasikan kembali pada tingkat bunga yang lebih rendah daripada coupon rate.

(6) Liquidity risk, yaitu resiko yang dihadapi investor karena obligasi tersebut tidak aktif diperdagangkan di bursa dan tidak ada harga yang jelas. Oleh karena itu, investor akan mencari obligasi yang aktif diperdagangkan di bursa.

Harga obligasi dinyatakan dalam persentase (\%) dari nilai nominal obligasi. Ada 3 macam harga obligasi yang ditawarkan, yaitu (www.bei.co.id): (1) Par (nilai Par), (2) At Premium (dengan premi) harga obligasi lebih besar dari nilai nominal, (3) At Discount (dengan diskon), dimana harga obligasi lebih kecil dari nilai nominal.

Harga obligasi merupakan nilai kini (present value) dari arus kas yang akan diterima investor yang didoskontokan dengan tingkat bunga pasar. Arus kas obligasi tanpa kupon adalah sebesar nilai par yang akan diterima pada saat jatuh tempo. Sedangkan arus kas coupon bond, terdiri atas kupon yang akan diterima investor setiap periode (enam bulanan atau tahunan) ditambah nilai pari obligasi tersebut pada waktu jatuh tempo. Makin panjang jangka waktu jatuh tempo, makin kecil harga obligasi dibandingkan dengan nilai par-nya. Makin besar tingkat bunga pasar, makin kecil harga obligasi dibanding terhadap nilai pari-nya. Jadi makin panjang dan makin besar tingkat bunga, maka harga obligasi akan semakin kecil dibandingkan dengan nilai par-nya, berarti makin besar keuntungan bagi pemegang obligasi tersebut. 


\section{Faktor Fundamental Perusahaan}

Faktor fundamental adalah fakta - fakta tentang kondisi ekonomi, keuangan dan operasional yang mempengaruhi nilai dasar dari perusahaan. Informasi menganai faktor fundamental perusahaan adalah hal penting untuk keberhasilan dan stabilitas jangka panjang perusahaan. Informasi tersebut diperoleh dari perhitungan rasio - rasio dalam laporan keuangan perusahaan, antara lain Coverage Ratio, Leverage Ratio, Liquidity Ratio,Profitability Ratio,Cash flow to debt ratio

\section{Faktor Fundamental Ekonomi}

Faktor fundamental ekonomi negara adalah faktor - faktor yang mempengaruhi kondisi ekonomi suatu negara yang bersifat sifatnya luas dan kompleks. Walaupun tidak ada satu faktor yang berpengaruh secara dominan, namun ada kerterkaitan satu sama lain antara faktor fundamental tersebut. Faktor fundamnetal negara dapat dikelompokkan menjadi empat, yaitu faktor ekonomi, faktor politik, faktor keuangan, faktor eskternal.

\section{Kerangka Pemikiran} INPUT

\section{PROSES}

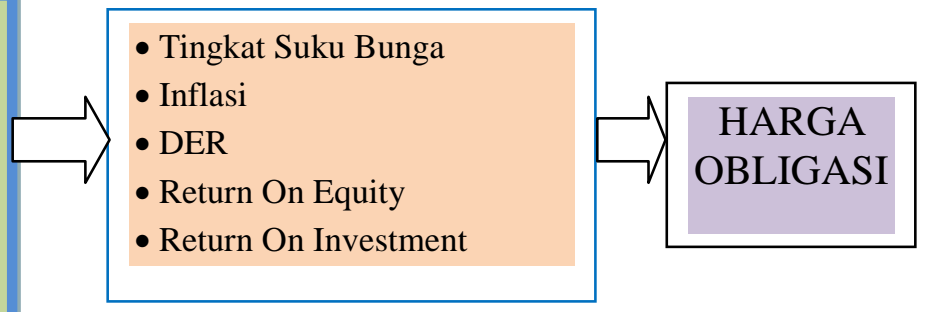

1.UU no.8 thn 1995 tentang Pasar Modal

2. PMK no.10/PMK.08/ $2007 \mathrm{ttg}$

Perubahan atas Peraturan

Penjualan Obligasi Ritel di pasar Perdana

3. Peraturan bapepam-LK

No.V.C. 3 ttg Lembaga

Penilaian Harga Efek

4. Peraturan PT. Bursa Efek

Surabaya No.I.A.3 SK-

020/LGL/BES/XI/2004 ttg

Kewajiban Pelaporan Emiten (untuk emiten Obligasi \& Sukuk)

\section{G. Hubungan Antar Variabel}

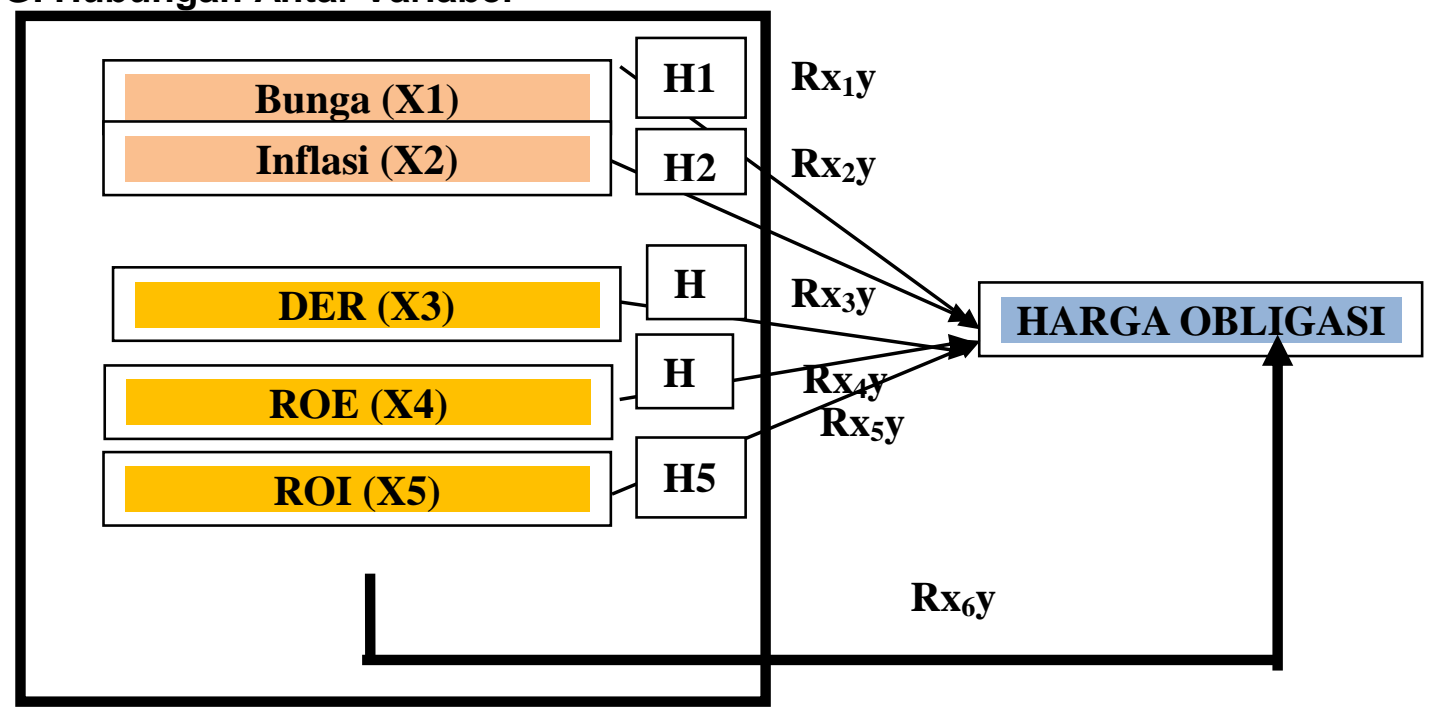




\section{Metodologi}

\section{Tempat dan Waktu Penelitian}

Pengambilan data emiten obyek penelitian dilakukan di Bursa Efek Indonesia (BEI) yang beralamat di Gedung Bursa Efek Indonesia Lantai 2 Tower 1, Jl. Jend. Sudirman Kav 52 - 53 SCBD, Jakarta dan melalui situs resmi Bursa Efek Indonesia (www.idx.co.id). Sedangkan data fundamental ekonomi yaitu inflasi dan suku bunga didapatkan melalui situs Bank Indonesia (www.bi.go.id).

\section{Tehnik Penentuan Data}

Dalam proses penentuan data agar sesuai dengan tujuan penelitian maka dipergunakan metode purposive sampling, dengan kriteria sampel sebagai berikut:

1. Sampel untuk Perusahaan emiten manufaktur adalah yang telah terdaftar dan aktif di Bursa Efek Indonesia dari tahun 2006 sampai tahun 2013.

2. Perusahaan emiten tersebut menerbitkan obligasi yang diperdagangkan di pasar sekunder dari tahun 2006 sampai dengan tahun 2013.

3. Menerbitkan dan menyampaikan laporan keuangan secara lengkap dan berkala dari tahun 2006 sampai dengan tahun 2013.

4. Emiten tidak pernah mengalami kerugian selama periode penelitian.

Berdasarkan kriteria di atas, maka terdapat 9 perusahaan yang menjadi sampel, dengan periode 8 tahun, maka total data yang akan diolah menjadi 69 sample.

\begin{tabular}{|c|l|c|}
\hline No & \multicolumn{1}{|c|}{ Nama Perusahaan Manufaktur } & Kode \\
\hline 1 & PT.Indofood Sukses Makmur, Tbk & INDF \\
\hline 2 & PT. Indah Kiat Tbk & INDF \\
\hline 3 & PT. Japfa Comfeed Indonesia, Tbk & JPFA \\
\hline 4 & PT. Malindo Feedmill, Tbk & MAIN \\
\hline 5 & PT. Mayora Indah, Tbk & MYOR \\
\hline 6 & PT. Ricky Putra Globalindo & RICY \\
\hline 7 & PT. Bentoel Internation Invest. TBK & RMBA \\
\hline 8 & PT. Selamat Sempurna & SMSM \\
\hline 9 & PT. Pabrik Kertas Tjiwi Kimia Tbk & TKIM \\
\hline
\end{tabular}

Sumber: Hasil Penelitian. (data diolah tahun 2014) 


\section{Hasil dan Pembahasan}

Metode analisis data yang digunakan dalam penelitian ini adalah metode statistik dengan menggunakan program SPSS versi 23.0.

\section{Uji Asumsi Klasik}

\section{Uji Normalitas}

Beberapa metode uji normalitas yaitu dengan melihat penyebaran data pada sumber diagonal pada grafik Normal P-P Plot of regression standardized residual atau dengan uji One Sample Kolmogorov Smirnov. Apabila Asymp.Sig > 0,05, maka data tersebut berdistribusi normal dan begitu juga sebaliknya (Singgih Santoso, $2012: 358$ ) untuk mengolah uji normalitas maka digunakan software IBM SPSS versi 22.00 for windows. Uji normalitas dapat dilihat pada tabel di bawah ini.

- Pendekatan Grafik

Hasil pengujian normalitas dengan menggunakan analisis grafik dapat dilihat pada gambar sebagai berikut :

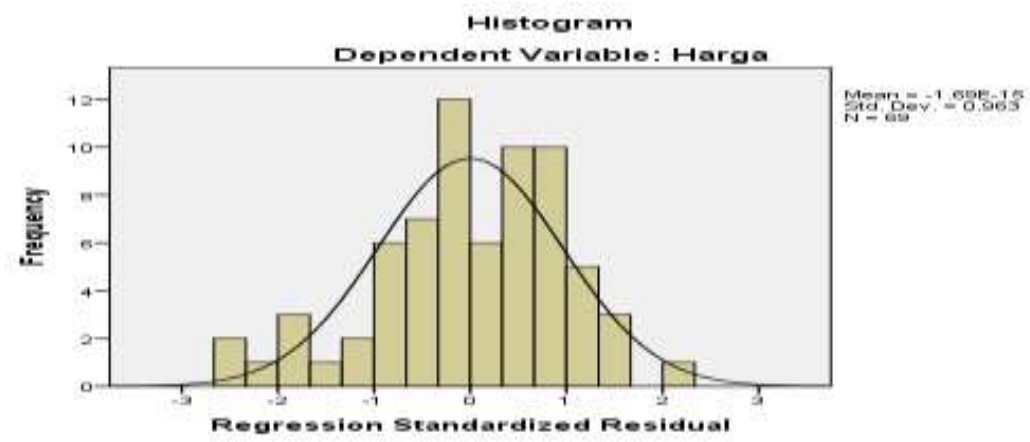

Sumber : Hasil penelitian, 2014 (data diolah dengan SPSS 22)

* Grafik P - Plot

Dengan cara membandingkan antara data observasi dengan distribusi yang mendekati garis normal, dari grafik diatas dapat disimpulkan bahwa distribusi data normal karena grafik histogram menunjukkan distribusi data menggunakan garis diagonal.

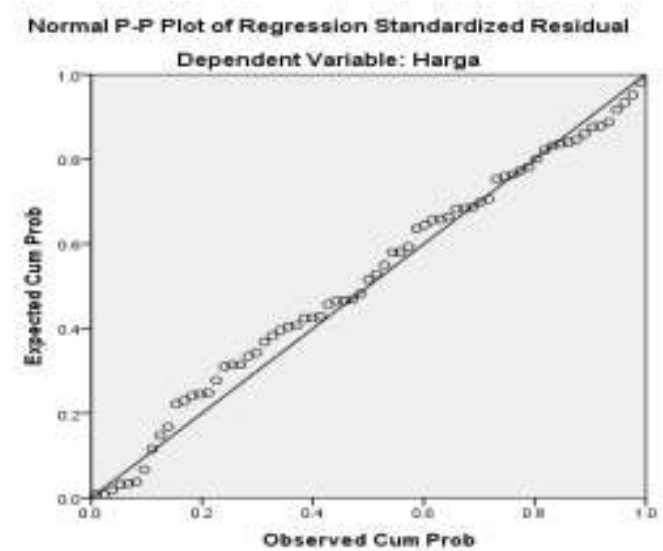

Sumber Hasil penelitian, 2014 (data diolah dengan SPSS 22) Model regresi tersebut memenuhi asumsi normalitas. 
- Pendekatan Kolmogorov Smirnov (KS)

Analisis statistik dengan menggunakan uji Kolmogorov Smirnov (KS) diperoleh hasil seperti yang dapat dilihat pada table sebagai berikut :

One-Sample Kolmogorov-Smirnov Test

\begin{tabular}{|ll|r|}
\hline & & $\begin{array}{c}\text { Unstandardi } \\
\text { zed } \\
\text { Residual }\end{array}$ \\
\hline $\mathrm{N}$ & & 69 \\
Normal Parameters & Mean & .0000000 \\
& Std. Deviation & .03293518 \\
Most Extreme & Absolute & .071 \\
Differences & Positive & .054 \\
& Negative & -.071 \\
Test Statistic & & .071 \\
Asymp. Sig. (2-tailed) & & $.200^{\mathrm{c}, \mathrm{d}}$ \\
\hline
\end{tabular}

Tabel 4.8 memperlihatkan bahwa nilai signifikansi variabel residual Asymp.Sig (2-tailed) > taraf nyata (a) yaitu 0,2 > 0,05 sehingga dapat disimpulkan bahwa data residual terdistribusi normal atau model telah memenuhi asumsi normalitas.

\section{Uji Heteroskedastisitas}

Hasil pengujian heteroskedastisitas dengan metode grafik dapat dilihat pada gambar berikut ini:

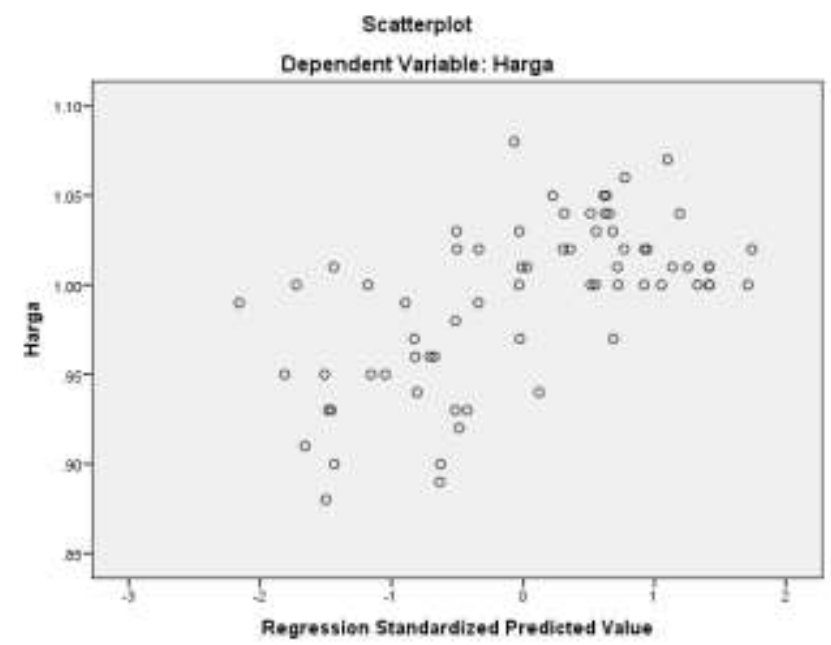

Sumber : Hasil penelitian, 2014 (data diolah dengan SPSS 22)

Hasil pengujian menunjukkan bahwa tidak ada pola yang jelas pada grafik scatter plot tersebut, semua titik - titik menyebar baik diatas maupun dibawah angka nol pada sumbu $Y$ grafik Scatter-plot. Hal ini menunjukkan bahwa tidak ada masalah heteroscedastisitas pada model regresi yang akan diuji 


\section{Uji Multikolinearitas}

Hasil pengujian multikolinearitas pada penelitian ini dapat dilihat pada tabel berikut ini:

\begin{tabular}{|ll|c|c|}
\hline \multirow{2}{*}{ Model } & \multicolumn{2}{|c|}{ Collinearity Statistics } \\
\cline { 2 - 3 } & Tolerance & VIF \\
\hline 1 & Bunga & .165 & 6.069 \\
& Inflasi & .168 & 5.945 \\
DER & .860 & 1.163 \\
ROE & .632 & 1.583 \\
ROI & .527 & 1.898 \\
\hline
\end{tabular}

a. Dependent Variable: Harga

Sumber : Hasil Penelitian, 2014 (data diolah dengan SPSS 22)

Berdasarkan hasil pengolahan data pada Tabel 4.13 menunjukkan tidak ada satupun variabel bebas yang memiliki nilai VIF lebih dari 10 dan nilai Tolerance kurang dari 0,1 maka dapat disimpulkan bahwa model regresi tidak terjadi masalah multikolinearitas.

\section{Uji Autokorelasi}

Gejala autokorelasi dideteksi dengan menggunakan Durbin-Watson test (Ghozali, 2006: 95). Hasil pengujian autokorelasi dapat dilihat sebagai berikut :

\begin{tabular}{|l|c|r|r|r|r|}
\hline Model & $\mathrm{R}$ & $\mathrm{R}$ Square & $\begin{array}{c}\text { Adjusted R } \\
\text { Square }\end{array}$ & $\begin{array}{c}\text { Std. Error of } \\
\text { the Estimate }\end{array}$ & $\begin{array}{c}\text { Durbin- } \\
\text { Watson }\end{array}$ \\
\hline 1 & $.601^{\mathrm{a}}$ & .361 & .310 & .03766 & .900 \\
\hline
\end{tabular}

a. Predictors: (Constant), ROI, Inflasi, DER, ROE, Bunga

b. Dependent Variable: Harga

Sumber : Hasil Penelitian, 2014 (Hasil diolah dengan SPSS 22)

Nilai d pada tabel autokorelasi dengan tingkat signifikansi 0.05 , jika jumlah sampel (N) 69 data dan jumlah variable bebas $(\mathrm{k})=5$, maka $\mathrm{dL}$ (batas bawah) $=1.464$ dan $\mathrm{dU}$ (batas atas) $=1.768$. Sedangkan hasil perhitungan, $\mathrm{d}$ hitung $=$ 0.896, maka didapatkan $\mathrm{dL}<$ dhitung $<\mathrm{dU}$, atau $0.900<1,426$ artinya terdapat autokorelasi.

\section{Analisa Regresi berganda}

Berdasarkan hasil perhitungan regresi berganda menggunakan SPSS versi 22 diperoleh hasil sebagai berikut : 


\begin{tabular}{|c|c|c|c|c|c|c|}
\hline \multirow{2}{*}{\multicolumn{2}{|c|}{ Model }} & \multicolumn{2}{|c|}{$\begin{array}{c}\text { Unstandardized } \\
\text { Coefficients }\end{array}$} & \multirow{2}{*}{$\begin{array}{c}\text { Standardize } \\
\text { d } \\
\text { Coefficients } \\
\text { Beta }\end{array}$} & \multirow[b]{2}{*}{$t$} & \multirow[b]{2}{*}{ Sig. } \\
\hline & & B & Std. Error & & & \\
\hline \multirow[t]{6}{*}{1} & (Constant) & 1.055 & .035 & & 30.404 & .000 \\
\hline & Bunga & -.230 & .692 & -.089 & -.333 & .740 \\
\hline & Inflasi & -.231 & .420 & -.145 & -.550 & .584 \\
\hline & DER & -.025 & .006 & -.430 & -3.967 & .000 \\
\hline & ROE & .048 & .045 & .134 & 1.053 & .296 \\
\hline & $\mathrm{ROI}$ & .073 & .083 & .120 & .877 & .384 \\
\hline
\end{tabular}

Sumber : Hasil Penelitian, 2014 (Hasil diolah dengan SPSS 22)

Dari hasil perhitungan pada tabel diatas dapat disajikan ke dalam bentuk persamaan regresi terstandardisasi sebagai berikut :

$$
\mathrm{Y}=1,055-0,230 \mathrm{X} 1-0,231 \mathrm{X} 2-0.025 \mathrm{X} 3+0.48 \mathrm{X} 4+0.73 \times 5
$$

Dimana :

$$
\begin{array}{llll}
\mathrm{Y} & =\text { Harga Obligasi, } & \mathrm{X} 1 & =\text { Suku bunga BI Rate } \\
\mathrm{X} 4 & =\text { Inflasi } & \mathrm{X} 3 & =\mathrm{DER} \\
\mathrm{X} 4 & =\mathrm{ROE} & \mathrm{X} 5 & =\mathrm{ROI}
\end{array}
$$

\section{Pengujian Hipotesis (Uji Statistik)}

Uji Parsial (Uji t) Untuk menguji pengaruh Suku Bunga, Inflasi, DER, ROE, dan $\mathrm{ROI}$ secara parsial terhadap harga Obligasi dapat menggunakan uji statistik $\mathrm{t}$ (uji t). Dengan taraf signifikansi $5 \%(0,05)$ dan derajat kebebasan $(\mathrm{dk})$ dengan rumus Dk $=\mathrm{n}-\mathrm{k}-1$, dimana $\mathrm{n}=$ Jumlah Responden, $\mathrm{k}=$ Jumlah variabel yang diteliti, kemudian membandingkan t hitung dengan $t$ tabel dengan kriteria sebagai berikut :

- Jika thitung > ttabel berarti $\mathrm{HO}$ ditolak dan $\mathrm{H} 1$ diterima

- Jika thitung < ttabel berarti $\mathrm{HO}$ diterima dan $\mathrm{H} 1$ ditolak

Dimana derajat kebebasannya adalah :

$$
\begin{aligned}
& \mathrm{Dk}=\mathrm{n}-\mathrm{k}-1=69-5-1=63 \\
& \text { Ttabel }=\mathrm{t}(\mathrm{a} ; \mathrm{dk})=(0,05 ; 63)=1,995
\end{aligned}
$$

\section{1) Pengaruh Suku Bunga $\left(X_{1}\right)$ terhadap Harga Obligasi}

Dengan hipotesa :

$\mathrm{H}_{1}=0$ diduga tidak ada pengaruh antara variabel suku bunga terhadap harga obligasi

$\mathrm{H}_{1} \neq 0$ diduga ada pengaruh signifikan antara variabel suku bunga terhadap harga obligasi

Maka dibawah ini adalah tabel hasil uji hipotesis untuk $\mathrm{H}_{1}$ yang diolah menggunakan SPSS versi 22 : 


\section{Coefficients $^{a}$}

\begin{tabular}{|c|c|c|c|c|c|}
\hline \multirow[b]{2}{*}{ Model } & \multicolumn{2}{|c|}{$\begin{array}{l}\text { Unstandardized } \\
\text { Coefficients }\end{array}$} & \multirow{2}{*}{$\begin{array}{c}\begin{array}{c}\text { Standardized } \\
\text { Coefficients }\end{array} \\
\text { Beta }\end{array}$} & \multirow[b]{2}{*}{$\mathrm{T}$} & \multirow[b]{2}{*}{ Sig. } \\
\hline & $B$ & Std. Error & & & \\
\hline (Constant) & 1.049 & .025 & & 42.318 & .000 \\
\hline Bunga & -.716 & .305 & -.275 & -2.343 & .022 \\
\hline
\end{tabular}

Sumber : Hasil Penelitian, 2014 (Hasil diolah dengan SPSS 22)

2) Pengaruh Inflasi $\left(X_{2}\right)$ terhadap Harga Obligasi

Dengan hipotesa :

$\mathrm{H}_{2}=0$ diduga tidak ada pengaruh antara variabel inflasi terhadap harga obligasi

$\mathrm{H}_{2} \neq 0$ diduga ada pengaruh signifikan antara variabel inflasi terhadap harga obligasi

Maka dibawah ini adalah tabel hasil uji hipotesis untuk $\mathrm{H}_{2}$ yang diolah menggunakan SPSS versi 22 :

\begin{tabular}{|rc|r|r|r|r|r|}
\hline \multirow{2}{*}{ Model } & \multicolumn{2}{|c|}{$\begin{array}{c}\text { Unstandardized } \\
\text { Coefficients }\end{array}$} & $\begin{array}{c}\text { Standardized } \\
\text { Coefficients }\end{array}$ & & \\
\cline { 2 - 5 } & \multicolumn{1}{|c|}{$\mathrm{B}$} & Std. Error & Beta & $\mathrm{t}$ & Sig. \\
\hline 1 & (Constant) & 1.020 & .013 & & 76.008 & .000 \\
& Inflasi & -.421 & .187 & -.265 & -2.247 & .028 \\
\hline
\end{tabular}

Sumber : Hasil Penelitian, 2014 (Hasil diolah dengan SPSS 22)

\section{3) Pengaruh DER $\left(\mathbf{X}_{3}\right)$ terhadap Harga Obligasi}

Dengan hipotesa :

$\mathrm{H}_{3}=0$ diduga tidak ada pengaruh antara variabel suku bunga terhadap harga obligasi

$\mathrm{H}_{3} \neq 0$ diduga ada pengaruh signifikan antara variabel suku bunga terhadap harga obligasi

Maka dibawah ini adalah tabel hasil uji hipotesis untuk $\mathrm{H}_{3}$ yang diolah menggunakan SPSS versi 22 :

\begin{tabular}{|c|c|c|c|c|c|}
\hline \multirow[b]{2}{*}{ Model } & \multicolumn{2}{|c|}{$\begin{array}{l}\text { Unstandardized } \\
\text { Coefficients }\end{array}$} & \multirow{2}{*}{$\begin{array}{c}\begin{array}{c}\text { Standardized } \\
\text { Coefficients }\end{array} \\
\text { Beta }\end{array}$} & \multirow[b]{2}{*}{$\mathrm{T}$} & \multirow[b]{2}{*}{ Sig. } \\
\hline & B & Std. Error & & & \\
\hline (Constant) & 1.042 & .011 & & 91.615 & .000 \\
\hline DER & -.030 & .006 & -.504 & -4.780 & .000 \\
\hline
\end{tabular}

Sumber : Hasil Penelitian, 2014 (Hasil diolah dengan SPSS 22) 


\section{4) Pengaruh ROE $\left(X_{4}\right)$ terhadap harga Obligasi}

Dengan Hipotesa :

$\mathrm{H}_{3}=0$ diduga tidak ada pengaruh antara variabel suku bunga terhadap harga obligasi

$\mathrm{H}_{3} \neq 0$ diduga ada pengaruh signifikan antara variabel suku bunga terhadap harga obligasi

Maka dibawah ini adalah tabel hasil uji hipotesis untuk $\mathrm{H}_{3}$ yang diolah menggunakan SPSS versi 22 :

\begin{tabular}{|c|c|c|c|c|c|}
\hline \multirow[b]{2}{*}{ Model } & \multicolumn{2}{|c|}{$\begin{array}{l}\text { Unstandardized } \\
\text { Coefficients }\end{array}$} & \multirow{2}{*}{\begin{tabular}{|c|}
$\begin{array}{c}\text { Standardized } \\
\text { Coefficients }\end{array}$ \\
Beta
\end{tabular}} & \multirow[b]{2}{*}{$\mathrm{T}$} & \multirow[b]{2}{*}{ Sig. } \\
\hline & $B$ & Std. Error & & & \\
\hline (Constant) & .977 & .009 & & 114.887 & .000 \\
\hline ROE & .096 & .042 & .267 & 2.272 & .026 \\
\hline
\end{tabular}

a. Dependent Variable: Harga

Sumber : Hasil Penelitian, 2014 (Hasil diolah dengan SPSS 22)

\section{5) Pengaruh ROI $\left(X_{5}\right)$ terhadap harga Obligasi}

Hipotesa :

$\mathrm{H}_{3}=0$ diduga tidak ada pengaruh antara variabel suku bunga terhadap harga obligasi

$\mathrm{H}_{3} \neq 0$ diduga ada pengaruh signifikan antara variabel suku bunga terhadap harga obligasi

Maka dibawah ini adalah tabel hasil uji hipotesis untuk $\mathrm{H}_{3}$ yang diolah menggunakan SPSS versi 22 :

\begin{tabular}{|c|c|c|c|c|c|c|}
\hline \multirow{2}{*}{\multicolumn{2}{|c|}{ Model }} & \multicolumn{2}{|c|}{$\begin{array}{l}\text { Unstandardized } \\
\text { Coefficients }\end{array}$} & \multirow{2}{*}{$\begin{array}{c}\begin{array}{c}\text { Standardized } \\
\text { Coefficients }\end{array} \\
\text { Beta }\end{array}$} & \multirow[b]{2}{*}{$\mathrm{T}$} & \multirow[b]{2}{*}{ Sig. } \\
\hline & & B & Std. Error & & & \\
\hline & (Constant) & .975 & .007 & & 134.264 & .000 \\
\hline & ROI & .230 & .069 & .377 & 3.335 & .001 \\
\hline
\end{tabular}

a. Dependent Variable: Harga

Sumber : Hasil Penelitian, 2014 (Hasil diolah dengan SPSS 22)

\section{Uji Simultan (Uji F)}

Uji F dilakukan untuk menguji pengaruh suku bunga, inflasi, DER, ROE dan ROI secara bersama-sama terhadap Harga Obligasi.

Dengan taraf signifikansi $5 \%(0,05)$ dan derajat kebebasan $(\mathrm{dk})$ dengan rumus

$\mathrm{dk}=\mathrm{n}-\mathrm{k}-1$, dimana $\mathrm{n}=$ Jumlah Responden, $\mathrm{k}=$ Jumlah variabel yang diteliti.

Kemudian membandingkan $\mathrm{F}_{\text {hitung }}$ dengan $\mathrm{F}_{\text {tabel }}$ dengan kriteria : 
- Jika $F$ hitung $\geq F$ tabel ( $\alpha, d k$ ), berarti Ho ditolak dan Ha diterima.

- Jika $F$ hitung $\leq F$ tabel ( $\alpha$, dk), berarti Ho diterima dan Ha ditolak.

Dimana derajat kebebasannya adalah :

$$
\begin{aligned}
& \text { Dk }=\mathrm{n}-\mathrm{k}-1=69-5-1=63 \\
& \mathrm{~F}_{\text {tabel }}=\mathrm{F}(\alpha ; \mathrm{dk})=(0,05 ; 63)=2,36
\end{aligned}
$$

$H_{0}: \rho_{Y X 1}=\rho_{Y X 2}=\rho_{Y X 3}=\rho_{Y X 4}=\rho_{Y X 5}=0$;

Artinya : tidak ada pengaruh tingkat suku bunga, inflasi, DER, ROE, ROI terhadap Harga Obligasi

$H_{1}: \rho_{Y X 1} \neq \rho_{Y X 2} \neq \rho_{Y X 3} \neq \rho_{Y X 4} \neq \rho_{Y X 5} \neq 0$;

Artinya : ada pengaruh tingkat suku bunga, inflasi, DER, ROE, ROI terhadap Harga Obligasi

Untuk menguji apakah terdapat pengaruh yang kuat secara simultan/keseluruhan antara $X_{1}$ (suku bunga), $X_{2}$ (inflasi) $X_{3}$ (DER), $X 4(R O E)$, $X 5(\mathrm{ROI})$ terhadap $\mathrm{Y}$ (harga obligasi), maka dapat dilihat dari hasil uji $\mathrm{F}$.

ANOVA $^{a}$

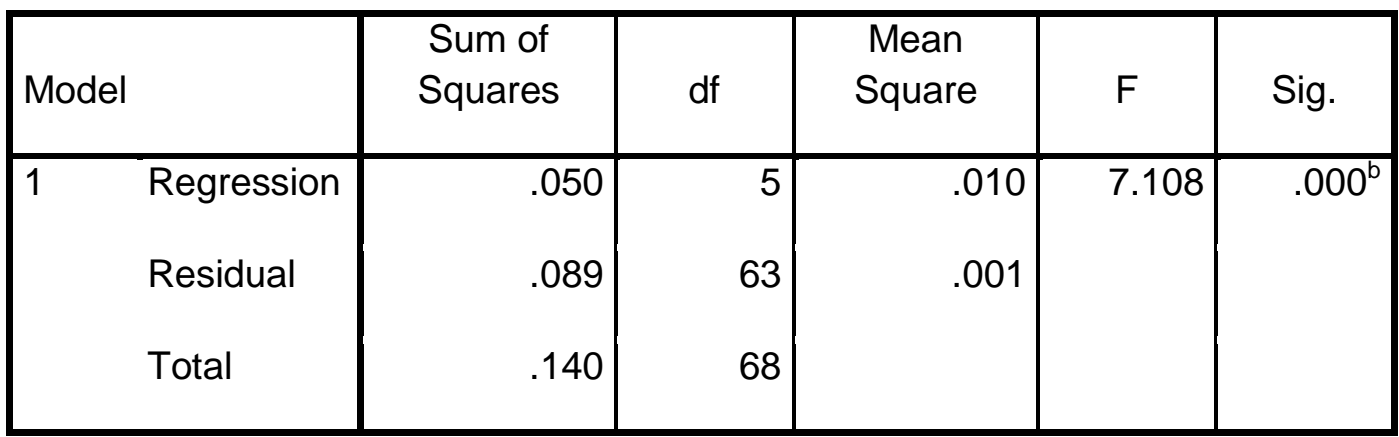

a. Dependent Variable: Harga

b. Predictors: (Constant), ROI, Inflasi, DER, ROE, Bunga

Sumber : Hasil Penelitian, 2014 (Hasil diolah dengan SPSS 22)

\section{Regresi Linier Berganda}

Uji Determinasi variabel suku bunga

\begin{tabular}{|c|c|c|c|c|}
\hline Model & $\mathrm{R}$ & $\mathrm{R}$ Square & $\begin{array}{c}\text { Adjusted } \mathrm{R} \\
\text { Square }\end{array}$ & $\begin{array}{c}\text { Std. Error of the } \\
\text { Estimate }\end{array}$ \\
\hline 1 & $.275^{\mathrm{a}}$ & .076 & .062 & .04391 \\
\hline
\end{tabular}

Sumber : Hasil Penelitian, 2014 (Hasil diolah dengan SPSS 22)

Dari tabel di atas dapat dilihat bahwa hasil pengujian Goodness of Fit (R2) 0,076 . Hal ini menunjukan bahwa pada pengaruh Bunga secara parsial tanpa variable lain yang diteliti terhadap harga obligasi sebesar $7,6 \%$, sisanya $92,4 \%$ dipengaruhi oleh variabel lain 


\section{Uji Determinasi variabel Inflasi}

\begin{tabular}{|c||c|c|c|}
\hline Model & R Square & Adjusted R Square & $\begin{array}{c}\text { Std. Error of the } \\
\text { Estimate }\end{array}$ \\
\hline 1 & .070 & .056 & .04405 \\
\hline
\end{tabular}

a. Predictors: (Constant), Inflasi

Sumber : Hasil Penelitian, 2014 (Hasil diolah dengan SPSS 22)

Dari tabel di atas dapat dilihat bahwa hasil pengujian Goodness of Fit (R2) 0,07 . Hal ini menunjukan bahwa pada pengaruh Inflasi secara parsial tanpa variable lain yang diteliti terhadap harga obligasi sebesar $7 \%$, sisanya $93 \%$ dipengaruhi oleh variabel lain

\section{1) Uji Determinasi Variabel DER}

\begin{tabular}{|c|c|c|c|c|}
\hline Model & $\mathrm{R}$ & $\mathrm{R}$ Square & Adjusted R Square & Std. Error of the Estimate \\
\hline 1 & $.504^{\mathrm{a}}$ & .254 & .243 & .03944 \\
\hline
\end{tabular}

predictors: (Constant), DER ,Dependent Variable: Harga

Sumber : Hasil Penelitian, 2014 (Hasil diolah dengan SPSS 22)

Dari tabel di atas dapat dilihat bahwa hasil pengujian Goodness of Fit (R2) 0,254 . Hal ini menunjukan bahwa pada pengaruh DER secara parsial tanpa variable lain yang diteliti terhadap harga obligasi sebesar $25,4 \%$, sisanya $74,6 \%$ dipengaruhi oleh variabel lain

2) Uji Determinasi Variabel ROE

\begin{tabular}{|c|r|r|r|r|}
\hline Model & $\mathrm{R}$ & R Square & \multicolumn{1}{c|}{$\begin{array}{c}\text { Adjusted } \mathrm{R} \\
\text { Square }\end{array}$} & Std. Error of the Estimate \\
\hline 1 & $.267^{\mathrm{a}}$ & .072 & .058 & .04401 \\
\hline
\end{tabular}

Sumber : Hasil Penelitian, 2014 (Hasil diolah dengan SPSS 22)

Predictors: (Constant), ROE, Dependent Variable: Harga

Dari tabel di atas dapat dilihat bahwa hasil pengujian Goodness of Fit (R2) 0,072 . Hal ini menunjukan bahwa pada pengaruh ROE secara parsial tanpa variable lain yang diteliti terhadap harga obligasi sebesar $7,2 \%$, sisanya $92,8 \%$ dipengaruhi oleh variabel lain. 


\section{3) Uji Determinasi variabel ROI}

\begin{tabular}{|l|r|r|r|r|}
\hline Model & $\mathrm{R}$ & $\mathrm{R}$ Square & Adjusted R Square & $\begin{array}{c}\text { Std. Error of the } \\
\text { Estimate }\end{array}$ \\
\hline 1 & $.377^{\mathrm{a}}$ & .142 & .130 & .04230 \\
\hline
\end{tabular}

b. Dependent Variable: Harga

Sumber : Hasil Penelitian, 2014 (Hasil diolah dengan SPSS 22)

Dari tabel di atas dapat dilihat bahwa hasil pengujian Goodness of Fit $\left(R^{2}\right)$ 0,142 . Hal ini menunjukan bahwa pada pengaruh $\mathrm{ROI}$ secara parsial tanpa variable lain yang diteliti terhadap harga obligasi sebesar $14,2 \%$, sisanya $85,7 \%$ dipengaruhi oleh variabel lain.

4) Uji Determinasi variabel suku bunga, inflasi, DER, ROE, ROI

\begin{tabular}{|c|c|c|c|c|}
\hline Model & $\mathrm{R}$ & $\mathrm{R}$ Square & $\begin{array}{c}\text { Adjusted } \mathrm{R} \\
\text { Square }\end{array}$ & $\begin{array}{c}\text { Std. Error of the } \\
\text { Estimate }\end{array}$ \\
\hline 1 & $.601^{\mathrm{a}}$ & .361 & .310 & .03766 \\
\hline
\end{tabular}

a. Predictors: (Constant), ROI, Inflasi, DER, ROE, Bunga

Sumber : Hasil Penelitian, 2014 (Hasil diolah dengan SPSS 22)

Dari tabel diatas dapat dilihat bahwa $\mathrm{R}$ Square sebesar 0,361 atau $36,1 \%$, hal ini menunjukkan bahwa pengaruh Bunga, Inflasi, DER, ROE, dan ROI secara bersama-sama terhadap Harga Obligasi sebesar 36,1 \% dan sisanya 63,9\% dipengaruhi oleh faktor lain yang tidak diteliti

\section{B. Pembahasan Penelitian}

Dari hasil perhitungan dengan mengguakan SPSS versi 22, dalam bentuk tabel sebagai berikut :

\begin{tabular}{|c|c|c|c|}
\hline No & $\begin{array}{c}\text { Variabe } \\
\text { I }\end{array}$ & Hipotesis & Hasil \\
\hline 1 & $\mathrm{H} 1$ & $\begin{array}{c}\text { Diduga terdapat pengaruh yang signifikan antara suku } \\
\text { bunga dengan harga obligasi perusahaan manufaktur }\end{array}$ & Diterima \\
\hline 2 & $\mathrm{H} 2$ & $\begin{array}{c}\text { Diduga terdapat pengaruh yang signifikan antara inflasi } \\
\text { dengan harga obligasi perusahaan manufaktur }\end{array}$ & Diterima \\
\hline 3 & $\mathrm{H} 3$ & $\begin{array}{c}\text { Diduga terdapat pengaruh yang signifikan antara DER } \\
\text { dengan harga obligasi perusahaan manufaktur }\end{array}$ & Diterima \\
\hline 4 & $\mathrm{H} 4$ & $\begin{array}{c}\text { Diduga terdapat pengaruh yang signifikan antara ROE } \\
\text { dengan harga obligasi perusahaan manufaktur }\end{array}$ & Diterima \\
\hline 5 & $\mathrm{H} 5$ & $\begin{array}{c}\text { Diduga terdapat pengaruh yang signifikan antara ROI } \\
\text { dengan harga obligasi perusahaan manufaktur }\end{array}$ & Diterima \\
\hline 6 & $\mathrm{H} 6$ & $\begin{array}{c}\text { Diduga terdapat pengaruh yang signifikan antara suku } \\
\text { bunga, inflasi, DER, ROE dan ROI dengan harga obligasi } \\
\text { perusahaan manufaktur }\end{array}$ & Diterima \\
\hline
\end{tabular}

Sumber : Hasil Penelitian, 2014 (Hasil diolah dengan SPSS 22) 
Berdasarkan ringkasan di atas maka dapat diuraikan sebagai berikut :

\section{Pengaruh Suku Bunga terhadap Harga Obligasi}

Korelasi antara tingkat suku bunga dengan harga obligasi perusahaan manufaktur adalah sebesar - 0,275. Karena korelasi $\neq 0$, maka hal ini berarti terdapat hubungan antara tingkat suku bunga dengan harga obligasi. Tanda negatif menunjukkan hubungan yang berlawanan arah terhadap harga obligasi, maka apabila suku bunga naik berakibat harga obligasi akan turun. Sedangkan nilai 0,275 berada dalam kisaran 0,25 - 0,5 termasuk dalam kategori korelasi yang cukup / sedang (Sarwono, 2006), maka hubungan antara tingkat suku bunga dengan harga obligasi berada pada kisaran sedang / cukup.

- Model regresi yang diperoleh adalah $Y=1,049-0,716 X_{1}$

- Konstanta sebesar 1,049 berarti bahwa tanpa adanya variabel suku bunga atau $X_{1}=0$, maka besarnya harga obligasi sebesar 1,049. Konstanta tersebut menunjukkan nilai awal dalam perhitungan pengaruh suku bunga terhadap harga obligasi.

- Sedangkan nilai - 0,716 $\mathrm{X}_{1}$ disebut juga slope atau derajat kemiringan yang menentukan arah dari regresi linier. Karena dalam hal ini nilai slope-nya negatif, artinya tingkat suku bunga mempunyai pengaruh yang berlawanan terhadap harga obligasi. Maka dengan nilai koefisien regresi sebesar 0,716 , berarti setiap kenaikan suku bunga sebesar $1 \%$ akan menyebabkan penurunan harga obligasi sebesar 0,716 atau $71,6 \%$ demikian pula sebaliknya, setiap penurunan tingkat suku bunga sebesar $1 \%$ maka harga obligasi akan naik sebesar $71,6 \%$.

- Nilai $\mathrm{R}^{2}$ sebesar 0,076 yang berarti besarnya kontribusi pengaruh suku bunga terhadap harga obligasi sebesar $7,6 \%$, sedangkan selebihnya $92,4 \%$ dipengaruhi oleh faktor lain selain suku bunga, misalnya pengaruh nilai tukar, rating perusahaan, kinerja perusahaan ataupun sentimen pasar obligasi lainnya.

- Uji t terhadap variabel suku bunga $\left(\mathrm{X}_{1}\right)$ didapatkan t hitung sebesar - 2,343 dengan signifikan t sebesar 0,022, karena t hitung lebih besar dari t tabel $(2.343>1,995)$ dan signifikansi lebih kecil dari $5 \%(0,022<0,05)$ maka secara parsial variabel suku bunga $\left(X_{1}\right)$ berpengaruh signifikan dan berlawanan arah terhadap variabel harga Obilgasi $(\mathrm{Y})$.

Bila tingkat bunga pasar naik, sehingga mendekati atau bahkan melebihi kupon /bunga obligasi yang diberikan oleh emiten maka nilai obligasi akan jatuh. Sebaliknya bila tingkat bunga pasar turun, maka harga obligasi manufaktur akan naik, karena nilai kupon yang akan diterima lebih besar daripada bunga pasar pada saat ini. Untuk investasi jangka panjang, seperti investasi obligasi sampai dengan 10 tahun, maka faktor suku bunga menjadi bahan pertimbangan utama. Karena semakin lama periode jatuh tempo obligasi maka resiko terhadap kenaikan suku bunga akan semakin tinggi. Dengan adanya kenaikan suku bunga, maka investor akan menyesuaikan portofolio investasinya dan melepas investasi yang sensitif terhadap kenaikan suku bunga. Pada perusahaan manufaktur, apabila suku bunga pasar naik, menyebabkan biaya bunga pinjaman juga akan naik, hal ini tentu akan 
menurunkan kemampuan perusahaan dalam membayar fixed cost, termasuk pembayaran kupon obligasi. Bila resiko gagal bayar oleh perusahaan naik, maka investor akan melepas obligasi ke pasar untuk menghindari kerugian investasi. Banyaknya penjualan obligasi ke pasar oleh investor tersebut menyebabkan harga obligasi akan turun. Demikian juga dalam perdagangan internasional, tekanan inflasi dapat menurunkan tingkat eksport barang, karena harga barang yang tidak kompetitif. Sebagai akibatnya produk luar negeri relatif lebih murah dibanding harga produk lokal. Mengingat sifat hubungan positif antara inflasi dengan tingkat suku bunga, maka pada saat inflasi naik maka suku bunga juga akan naik, akibatnya investor akan mengalihkan dananya pada investasi yang menjanjikan return lebih tinggi dan menjual instrumen investasi dalam portfolio perusahaannya. Maka tekanan menjual ini akan menurunkan harga obligasi tersebut.

\section{Pengaruh Inflasi terhadap harga Obligasi}

Hal Penelitian secara detail dijelaskan dengan perhitungan statistik dalam uji parsial dan uji koefisien determinasi, dengan penjelasan sebagai berikut :

- Korelasi antara tingkat inflasi dengan harga obligasi perusahaan manufaktur adalah sebesar - 0,265 maka karena korelasi $\neq 0$, hal ini berarti terdapat hubungan antara tingkat suku bunga dengan harga obligasi. Tanda negatif menunjukkan hubungan yang berlawanan arah terhadap harga obligasi, maka apabila inflasi naik berakibat harga obligasi akan turun yang berarti. Sedangkan nilai 0,265 masih berada pada kisaran 0,25 - 05 termasuk dalam kategori korelasi yang cukup / sedang (Sarwono, 2006), maka hubungan antara tingkat suku bunga dengan harga obligasi berada pada kisaran sedang / cukup

- Model regresi yang diperoleh adalah $Y=1,02-0,421 X_{2}$

- Konstanta sebesar 1,02 berarti tanpa adanya variabel inflasi, atau X2 $=0$, maka besarnya harga obligasi sebesar 1,02 atau $102 \%$ (harga premium). Konstanta tersebut menunjukkan bahwa nilai awal harga obligasi dalam perhitungan pengaruh inflasi terhadap harga obligasi adalah $102 \%$

- Sedangkan nilai - $0,421 \mathrm{X}_{2}$ disebut juga slope atau derajat kemiringan yang menentukan arah dari regresi linier. Karena dalam hal ini nilai slopenya negatif, artinya tingkat suku bunga mempunyai pengaruh yang berlawanan terhadap harga obligasi. Maka dengan nilai koefisien regresi sebesar 0,421 , berarti setiap kenaikan suku bunga sebesar satu persen akan menyebabkan penurunan harga obligasi sebesar 0,421 atau $42,1 \%$ demikian pula sebaliknya, setiap penurunan tingkat suku bunga sebesar 1 $\%$ maka harga obligasi akan naik sebesar $42,1 \%$.

- Nilai $\mathrm{R}^{2}$ sebesar 0,070 yang berarti besarnya kontribusi pengaruh suku bunga terhadap harga obligasi sebesar 7\%, yang berarti tingkat inflasi memberi kontribusi sebesar 7\% terhadap Harga Obligasi dan selebihnya 93\% dipengaruhi oleh faktor lain selain inflasi, misalnya pengaruh nilai tukar, rating perusahaan, kinerja perusahaan ataupun sentimen pasar obligasi lainnya.

- Uji $\mathrm{t}$ terhadap variabel inflasi $\left(\mathrm{X}_{2}\right)$ didapatkan thitung sebesar - 2,247 dengan signifikan t sebesar 0,022, karena t hitung lebih besar dari $t$ 
tabel $(2.247>1,995)$ dan signifikansi lebih kecil dari $5 \%(0,028<0,05)$ maka secara parsial variabel inflasi $\left(\mathrm{X}_{2}\right)$ berpengaruh signifikan dan berlawanan arah terhadap variabel harga Obilgasi $(\mathrm{Y})$.

Hal ini menjelaskan bahwa salah satu faktor resiko dalam obligasi adalah purchasing power risk, yaitu resiko yang disebabkan oleh kenaikan inflasi. Bila inflasi naik, apalagi bila kenaikannya melebihi tingkat suku bunga pasar maka harga obligasi akan jatuh. Kenaikan inflasi akan menggerus return obligasi tersebut, karena nilai kupon yang diterima investor adalah tetap, sementara daya belinya akan turun dengan adanya inflasi. Untuk investasi jangka panjang, seperti investasi obligasi sampai dengan 10 tahun, maka faktor inflasi menjadi bahan pertimbangan utama. Karena dengan adanya penurunan daya beli uang, maka investor akan menyesuaikan portofolio investasinya dan melepas investasi yang sensitif terhadap kenaikan inflasi. Inflasi berpengaruh pada perusahaan yang memproduksi barang konsumsi. Karena kenaikan inflasi menyebabkan kenaikan harga jual barang sehingga mempengaruhi pendapatan ata penjualan. Dengan menurunnya pendapatan, maka kemampuan perusahaan untuk menutup biaya operasional khususnya biaya tetap termasuk untuk pembayaran kewajiban bunga obligasi atau bunga hutang kredit lainnya juga akan menurun. Bila resiko gagal bayar oleh perusahaan naik, maka investor akan melepas obligasi ke pasar untuk menghindari kerugian investasi. Banyaknya penjualan obligasi ke pasar oleh investor tersebut menyebabkan harga obligasi akan turun. Demikian juga dalam perdagangan internasional, tekanan inflasi dapat menurunkan tingkat eksport barang, karena harga barang yang tidak kompetitif. Sebagai akibatnya produk luar negeri relatif lebih murah dibanding harga produk lokal. Mengingat sifat hubungan positif antara inflasi dengan tingkat suku bunga, maka pada saat inflasi naik maka suku bunga juga akan naik, akibatnya investor akan mengalihkan dananya pada investasi yang menjanjikan return lebih tinggi dan menjual instrumen investasi dalam portfolio perusahaannya. Maka tekanan menjual ini akan menurunkan harga obligasi tersebut. Penelitian ini tidak sejalan dengan hasil Penelitian Jung Sen (2012) yang menyebutkan bahwa inflasi tidak berpengaruh terhadap harga obligasi. Namun penelitian ini sejalan dengan pernyataan Zubir $(2012 ; 7)$ yang menyebutkan bahwa resiko yang disebabkan inflasi akan memperkecil return obligasi tersebut.

\section{Pengaruh DER terhadap harga Obligasi}

Hasil penelitian menunjukkan adanya penurunan tingkat penggunaan hutang sebagai sumber pembiayaan. Lebih jelasnya hal ini diterangkan dalam hasil perhitungan statistik tersebut adalah sebagai berikut :

- Korelasi antara DER dengan harga obligasi perusahaan manufaktur adalah sebesar - 0,504 maka karena korelasi $\neq 0$, hal ini berarti terdapat hubungan antara tingkat suku bunga dengan harga obligasi. Tanda negatif menunjukkan hubungan yang berlawanan arah terhadap harga obligasi, maka apabila nilai DER naik berakibat harga obligasi akan turun. Sedangkan nilai 0,504 masih berada pada kisaran $0,5-0,75$ termasuk dalam kategori korelasi yang kuat (Sarwono, 2006), maka hubungan antara tingkat DER dengan harga obligasi cukup kuat 
- $\quad$ Model regresi yang diperoleh adalah $Y=1,042-0,03 X_{3}$

- Konstanta sebesar 1,042 berarti tanpa adanya variabel DER, atau $X_{3}=0$, maka besarnya harga obligasi sebesar 1,042 atau 104,2\%.

Konstanta tersebut menunjukkan bahwa nilai awal harga obligasi dalam perhitungan pengaruh inflasi terhadap harga obligasi adalah 104,2\%.

- Variabel tingkat DER mempunyai pengaruh yang negatif (berlawanan arah) terhadap harga obligasi dengan nilai koefisien regresi sebesar - 0,03 yang berarti jika variabel DER meningkat satu satuan maka Harga Obligasi akan turun sebesar 0,03.

- Sedangkan nilai $-0,03 \mathrm{X}_{3}$ disebut juga slope atau derajat kemiringan yang menentukan arah dari regresi linier. Karena dalam hal ini nilai slope-nya negatif, artinya DER mempunyai pengaruh yang berlawanan terhadap harga obligasi. Maka dengan nilai koefisien regresi sebesar 0,03 , berarti setiap kenaikan DER satu satuan akan menyebabkan penurunan harga obligasi sebesar 0,03 atau $3 \%$ demikian pula sebaliknya, setiap penurunan DER sebesar 1 satuan maka harga obligasi akan naik sebesar $3 \%$.

- Nilai $R^{2}$ sebesar 0,254 yang berarti besarnya kontribusi pengaruh DER terhadap harga obligasi 25,4\% terhadap Harga Obligasi, dan selebihnya 74,6\% dipengaruhi oleh faktor lain selain DER, misalnya bond rating, nilai tukar, sentimen pasar ataupun pengaruh lain secara simultan. Namun untuk pengujian secara parsial, kontribusi pengaruh sebesar 25,4\% ini adalah cukup berarti pengaruhnya diantara berbagai macam pengaruh yang lain terhadap harga obligasi seperti misalnya bond rating, besarnya kupon yang tawarkan, dll. Sehingga investor seharusnya mempertimbangkan faktor DER ini dalam berinvestasi obligasi perusahaan manufaktur.

- $\quad U j i \quad t$ terhadap variable DER $\left(X_{3}\right)$ didapatkan $t$ hitung sebesar - 4,780 dengan signifikan $t$ sebesar 0,000 , karena $t$ hitung lebih besar dari $t$ tabel $(4,780>1,995)$ dan signifikansi lebih kecil dari $5 \%(0,000<0,05)$ maka secara parsial variabel DER $\left(\mathrm{X}_{3}\right)$ berpengaruh signifikan dan berlawanan arah terhadap variabel harga Obilgasi $(Y)$.

Bila DER perusahaan manufaktur naik, maka harga obligasi yang diterbitkannya akan turun. Nilai DER yang meningkat menunjukkan bahwa perusahaan menggunakan leverage keuangan (hutang yang meningkat). Semakin meningkatnya hutang, maka resiko untuk gagal bayar yang semakin tinggi. Semakin besar resiko gagal bayar maka permintaan akan obligasi semakin menurun. Menurunnya permintaan obligasi menyebabkan turunnya harga obligasi. DER yang terlalu tinggi menunjukkan perusahaan kelebihan beban utang dan pertanda resiko gagal bayar yang besar karena perusahaan tidak mampu memenuhi kewajibannya. Hal ini sejalan dengan penelitian Hutajulu (2008) yang menyebutkan bahwa harga debt to equity ratio berpengaruh signifikan terhadap Imbal hasil Obligasi, yang mana Imbal hasil obligasi yang merupakan salah satu faktor penentu besarnya harga obligasi, namun penelitian ini tidak sama dengan yang dihasilkan dari penelian Jung Sen (2012) yang menyebutkan bahwa secara parsial DER tidak berpengaruh terhadap harga Obligasi. 


\section{Pengaruh ROE terhadap harga Obligasi}

Hasil uji statistic dalam penelitian ini menunjukkan bahwa :

- Korelasi antara ROE dengan harga obligasi perusahaan manufaktur adalah sebesar 0,267 , maka karena korelasi $\neq 0$, hal ini berarti terdapat hubungan antara tingkat suku bunga dengan harga obligasi yang berarti ada pengaruh positif yang rendah antara ROE dan harga obligasi. Artinya apabila ROE naik maka harga obligasi akan naik.

Sedangkan nilai 0,267 berada dalam kisaran 0,25 - 0,5 termasuk dalam kategori korelasi yang cukup / sedang (Sarwono, 2006), maka hubungan antara tingkat suku bunga dengan harga obligasi berada pada kisaran sedang / cukup.

- $\quad$ Model regresi yang diperoleh adalah $Y=0,977+0.096 X_{4}$

- Konstanta sebesar 0,977 berarti tanpa adanya variabel $\mathrm{ROE}$, atau $\mathrm{X}_{4}=$ 0, maka besarnya harga obligasi sebesar 0,977 atau $97,7 \%$

Konstanta tersebut menunjukkan bahwa nilai awal harga obligasi dalam perhitungan pengaruh ROE terhadap harga obligasi adalah $97,7 \%$.

- Sedangkan nilai $0,096 \mathrm{X}_{4}$ disebut juga slope atau derajat kemiringan yang menentukan arah dari regresi linier. Karena dalam hal ini nilai slope-nya positif, artinya ROE mempunyai pengaruh yang searah terhadap harga obligasi. Maka dengan nilai koefisien regresi sebesar 0,096, berarti setiap kenaikan ROE satu satuan akan menyebabkan penurunan harga obligasi sebesar 0,096 atau 9,6\% demikian pula sebaliknya, setiap penurunan ROE sebesar 1 satuan maka harga obligasi akan naik sebesar $9,6 \%$.

- Nilai $\mathrm{R}^{2}$ sebesar 0,072 yang berarti besarnya kontribusi pengaruh ROE terhadap harga obligasi $7,2 \%$ terhadap Harga Obligasi, dan selebihnya $92,8 \%$ dipengaruhi oleh faktor lain selain ROE, misalnya bond rating, nilai tukar, DER, sentimen pasar lain ataupun pengaruh lain secara simultan.

- Uji $t$ terhadap variabel $\operatorname{ROE}\left(X_{4}\right)$ didapatkan $t$ hitung sebesar 2,272 dengan signifikan t sebesar 0,026, karena t hitung lebih besar dari $t$ tabel $(2.272>1,995)$ dan signifikansi lebih kecil dari $5 \%(0,026<0,05)$ maka secara parsial variabel $\mathrm{ROE}\left(\mathrm{X}_{4}\right)$ berpengaruh positif dan signifikan terhadap variabel harga Obligasi $(\mathrm{Y})$.

Nilai ROE yang tinggi menunjukkan pertumbuhan perusahaan sehingga memiliki prospek masa depan yang baik. Dengan demikian maka persepsi investor terhadap perusahaan tersebut akan naik dan meningkatkan permintaan obligasi. Meningkatkan permintaan obligasi akan berdampak pada meningkatnya harga obligasi. Hal ini sejalan dengan penelitian Bodie (2006).

\section{Pengaruh ROI terhadap harga Obligasi}

Dari hasil perhitungan statistik dijelaskankan bahwa :

- Korelasi antara ROE dengan harga obligasi perusahaan manufaktur adalah sebesar 0,377 , maka karena korelasi $\neq 0$, hal ini berarti terdapat hubungan antara tingkat suku bunga dengan harga obligasi yang berarti ada pengaruh positif yang rendah antara ROI dan harga obligasi. Artinya 
apabila $\mathrm{ROI}$ naik maka harga obligasi akan naik.

Sedangkan nilai 0,377 berada dalam kisaran 0,25 - 0,5 termasuk dalam kategori korelasi yang cukup / sedang (Sarwono, 2006), maka hubungan antara tingkat suku bunga dengan harga obligasi berada pada kisaran sedang / cukup.

- Model regresi yang diperoleh adalah $Y=0,975+0.069 X_{5}$

- Konstanta sebesar 0,975 berarti tanpa adanya variabel $\mathrm{ROI}$, atau $\mathrm{X}_{4}=$ 0 , maka besarnya harga obligasi sebesar 0,975 atau $97,5 \%$. Konstanta tersebut menunjukkan bahwa nilai awal harga obligasi dalam perhitungan pengaruh $\mathrm{ROI}$ terhadap harga obligasi adalah $97,5 \%$.

- Sedangkan nilai $0,069 X_{5}$ disebut juga slope atau derajat kemiringan yang menentukan arah dari regresi linier. Karena dalam hal ini nilai slope-nya positif, artinya ROI mempunyai pengaruh yang searah terhadap harga obligasi. Maka dengan nilai koefisien regresi sebesar 0,069 , berarti setiap kenaikan ROI satu satuan akan menyebabkan penurunan harga obligasi sebesar 0,069 atau 6,9\% demikian pula sebaliknya, setiap penurunan $\mathrm{ROI}$ sebesar 1 satuan maka harga obligasi akan naik sebesar 6,9\%.

- Nilai $\mathrm{R}^{2}$ sebesar 0,142 yang berarti besarnya kontribusi pengaruh ROE terhadap harga obligasi $14,2 \%$ terhadap Harga Obligasi, dan selebihnya $85,8 \%$ dipengaruhi oleh faktor lain selain ROE, misalnya bond rating, nilai tukar, DER, sentimen pasar lain ataupun pengaruh lain secara simultan.

- Uji $t$ terhadap variabel $\mathrm{ROI}\left(\mathrm{X}_{5}\right)$ didapatkan $\mathrm{t}$ hitung sebesar 3,335 dengan signifikan t sebesar 0,001, karena t hitung lebih besar dari t tabel $(3,335>1,995)$ dan signifikansi lebih kecil dari $5 \%(0,001<0,05)$ maka secara parsial variabel $\mathrm{ROI}\left(\mathrm{X}_{5}\right)$ berpengaruh positif dan signifikan terhadap variabel harga Obligasi $(\mathrm{Y})$.

Bila ROI perusahaan manufaktur naik, maka harga obligasi yang diterbitkannya akan naik. Nilai ROI yang tinggi menunjukkan perusahaan mampu memberikan laba operasi yang besar dan mampu memenuhi kewajiban membayar bunga atas hutang - hutangnya. Dengan demikian maka persepsi investor terhadap perusahaan tersebut akan naik dan meningkatkan permintaan obligasi. Meningkatkan permintaan obligasi akan berdampak pada meningkatnya harga obligasi. Hal ini sejalan dengan penelitian Bodie (2006).

\section{Pengaruh tingkat suku bunga, inflasi, DER, ROE dan ROI terhadap harga Obligasi perusahaan}

Hasil uji simultan pengaruh fundamental ekonomi yang dinyatakan dalam ratio suku bunga, inflasi, dan pengaruh fundamental perusahaan yang dinyatakan dalam ratio DER, ROE dan ROI terhadap harga obligasi perusahaan manufaktur dijelaskan bahwa

- Korelasi antara antara suku bunga, inflasi, DER, ROE dan ROI secara simultan terhadap harga obligasi perusahaan manufaktur adalah sebesar 0,601 , maka karena korelasi $\neq 0$, hal ini berarti terdapat hubungan antara suku bunga, inflasi, DER, ROE dan ROI secara simultan dengan harga obligasi. Sedangkan nilai 0,601 berad pada kisaran $0,5-0,75$ yang berarti 
ada korelasi positif yang kuat antara suku bunga, inflasi, DER, ROE dan ROI secara simultan terhadap harga obligasi (sarwono, 2006). Artinya apabila suku bunga, inflasi, DER, ROE dan ROI secara simultan naik maka harga obligasi akan naik.

- Model regresi yang diperoleh adalah $Y=1,055-0,230 X_{1}-0,231 X_{2}-0,025 X_{3}+0,48 X_{4}+0,73 X_{5}$

- Konstanta sebesar 1,055 berarti tanpa variabel suku bunga, inflasi, DER, ROE, dan ROI besarnya harga obligasi sebesar 1,055 atau $105,5 \%$. Konstanta tersebut menunjukkan bahwa nilai awal harga obligasi dalam perhitungan pengaruh suku bunga, inflasi, DER, ROE, dan ROI terhadap harga obligasi adalah 105,5\%.

- Variabel suku bunga mempunyai pengaruh negatif terhadap harga obligasi dengan nilai koefisien regresi sebesar 0,230 yang berarti jika variabel suku bunga meningkat satu satuan maka Harga Obligasi akan naik sebesar 0,230 atau $23 \%$

- Variabel inflasi mempunyai pengaruh negatif terhadap harga obligasi dengan nilai koefisien regresi sebesar 0,231 yang berarti jika variabel inflasi meningkat satu satuan maka Harga Obligasi akan naik sebesar 0,231 atau $23,1 \%$

- Variabel DER mempunyai pengaruh negatif terhadap harga obligasi dengan nilai koefisien regresi sebesar 0,025 yang berarti jika variabel DER meningkat satu satuan maka Harga Obligasi akan naik sebesar 0,025 atau $2,5 \%$

- Variabel ROE mempunyai pengaruh positif terhadap harga obligasi dengan nilai koefisien regresi sebesar 0,48 yang berarti jika variabel ROE meningkat satu satuan maka Harga Obligasi akan naik sebesar 0,48 atau $48 \%$

- Variabel ROI mempunyai pengaruh positif terhadap harga obligasi dengan nilai koefisien regresi sebesar 0,73 yang berarti jika variabel inflasi meningkat satu satuan maka Harga Obligasi akan naik sebesar 0,73 , atau $73 \%$

- Nilai $\mathrm{R}^{2}$ sebesar 0,361 yang berarti suku bunga, inflasi, DER, ROE dan ROI secara simultan memberi kontribusi sebesar 36,1\% terhadap Harga Obligasi dan selebihnya $63,9 \%$ dipengaruhi oleh faktor lain misalnya bond rating, besarnya kupon, imbal hasil obligasi, atau sentimen pasar lain baik secara partial maupun secara bersama-sama.

- Nilai $F$ hitung sebesar 7,108, dengan signifikansi sebesar 0,00. Nilai $F_{\text {tabel }}$ $=\mathrm{t}(0.05 ; 63)=2,360$, karena $\mathrm{F}$ hitung lebih besar dari $\mathrm{F}$ tabel $(7,108>$ $2,360)$ dan signifikansi lebih kecil dari $5 \%(0,00<0,05)$ maka secara simultan variabel suku bunga, inflasi, ROE dan ROI berpengaruh positif dan signifikan terhadap variabel harga Obligasi.

Hipotesis dalam penelitian ini adalah diduga ada pengaruh signifikan antara Fundamental ekonomi dan perusahaan terhadap harga obligasi perusahaan manufaktur yang terdaftar di Bursa Efek Indonesia, maka dari hasil pengujian statistik tersebut diperoleh hasil bahwa terdapat pengaruh yang signifikan antara Fundamental ekonomi dan perusahaan terhadap harga obligasi 
perusahaan manufaktur. Besarnya kontribusi pengaruh tersebut adalah 36,1\%. Nilai kontribusi ini cukup untuk dijadikan pertimbangan bagi investor yang akan berinvestasi obligasi pada perusahaan manufaktur. Hal ini selaras dengan hasil penelitian Jung sen (2012) yang menyebutnya bahwa terdapat pengaruh yang signifikan antara fundamental ekonomi dan perusahaan terhadap harga obligasi. Dan juga selaras dengan penelitian Hutajulu (2008) yang menyebutkan ada pengaruh signifikan antara fundamental ekonomi dan perusahaan terhadap imbal hasil obligasi.

\section{G. Kesimpulan}

1. Tingkat suku bunga mempunyai pengaruh yang sedang / cukup dan signifikan serta berlawanan arah terhadap Harga Obligasi. Dengan demikian tinggi rendahnya harga obligasi dipengaruhi oleh suku bunga. Besarnya kontribusi suku bunga yang secara langsung berkontribusi terhadap harga obligasi adalah sebesar $7,2 \%$. Berdasarkan penelitian ini dapat disimpulkan bahwa hipotesis penelitian yang menyatakan "Terdapat pengaruh antara suku bunga dengan harga obligasi peruahaan manufaktur" dapat diterima.

2. Tingkat inflasi mempunyai pengaruh yang sedang / cukup dan signifikan serta berlawanan arah terhadap Harga Obligasi. Dengan demikian tinggi rendahnya harga obligasi dipengaruhi oleh inflasi. Besarnya kontribusi inflasi yang secara langsung berkontribusi terhadap harga obligasi adalah sebesar 7,0\%. Berdasarkan penelitian ini dapat disimpulkan bahwa hipotesis penelitian yang menyatakan "Terdapat pengaruh antara inflasi dengan harga obligasi perusahaan manufaktur" dapat diterima.

3. Debt to Equity Ratio (DER) mempunyai pengaruh yang kuat dan signifikan serta berlawanan arah terhadap Harga Obligasi. Dengan demikian tinggi rendahnya harga obligasi dipengaruhi oleh DER. Besarnya kontribusi DER yang secara langsung berkontribusi terhadap harga obligasi adalah sebesar $25,4 \%$. Berdasarkan penelitian ini dapat disimpulkan bahwa hipotesis penelitian yang menyatakan "Terdapat pengaruh antara DER dengan harga obligasi perusahaan manufaktur" dapat diterima.

4. Return On Equity (ROE) mempunyai pengaruh yang sedang / cukup dan signifikan terhadap Harga Obligasi. Dengan demikian tinggi rendahnya harga obligasi dipengaruhi oleh ROE. Besarnya kontribusi ROE yang secara langsung berkontribusi terhadap harga obligasi adalah sebesar $7,2 \%$. Berdasarkan penelitian ini dapat disimpulkan bahwa hipotesis penelitian yang menyatakan "Terdapat pengaruh antara ROE dengan harga obligasi perusahaan manufaktur" dapat diterima.

5. Return On Investment (ROI) mempunyai pengaruh yang sedang / cukup dan signifikan terhadap Harga Obligasi. Dengan demikian tinggi rendahnya harga obligasi dipengaruhi oleh ROI. Besarnya kontribusi ROI yang secara langsung berkontribusi terhadap harga obligasi adalah sebesar $14,2 \%$. Berdasarkan penelitian ini dapat disimpulkan bahwa hipotesis penelitian yang menyatakan "Terdapat pengaruh antara ROI dengan harga obligasi perusahaan manufaktur" dapat diterima.

6. Secara simultan,tingkat suku bunga, inflasi, Debt to Equity Ratio, Return On Equity dan Return On Investment berpengaruh secara kuat dan signifikan terhadap Harga Obligasi. Besarnya kontribusi secara simultan sebesar 36,1\%, sedangkan sisanya yaitu sebesar $73,9 \%$ merupakan pengaruh yang datang dari faktor - faktor lain, misalnya rating obligasi, besarnya kupon yang diberikan, 
besarnya imbal hasil obligasi, dan lain-lain. Berdasarkan penelitian ini dapat disimpulkan bahwa hipotesis penelitian yang menyatakan "Terdapat pengaruh antara suku bunga, inflasi, Debt to Equity Ratio, Return On Equity dan Return On Investment secara simultan terhadap harga obligasi peruahaan manufaktur" dapat diterima.

\section{H. Daftar Pustaka}

Anoraga. Pandji dan Pakarti Fiji. 2001. Pengantar Pasar Modal. Edisi Revisi. PT Asdi Mahasatya. Jakarta.

Agency, Indonesia Bond Pricing \& Indonesia Stock Exchange, 2008, Indonesia Bond Market Directory 2008, Indonesia Stock Exchange, Jakarta

Agency, Indonesia Bond Pricing \& Indonesia Stock Exchange, 2009 , Indonesia Bond Market Directory 2009, Indonesia Stock Exchange, Jakarta

Agency, Indonesia Bond Pricing \& Indonesia Stock Exchange, 2010, Indonesia Bond Market Directory 2010, Indonesia Stock Exchange, Jakarta

Agency, Indonesia Bond Pricing \& Indonesia Stock Exchange, 2011, Indonesia Bond Market Directory 2011, Indonesia Stock Exchange, Jakarta

Agency, Indonesia Bond Pricing \& Indonesia Stock Exchange, 2012, Indonesia Bond Market Directory 2012, Indonesia Stock Exchange, Jakarta

Agency, Indonesia Bond Pricing \& Indonesia Stock Exchange, 2013, Indonesia Bond Market Directory 2013, Indonesia Stock Exchange, Jakarta

Bodie Zvi, Kane Alex dan Marcus Alan J. 2009. Investment. Edisi ke delapan. Salemba Empat. Jakarta.

Exchange, Indonesia Stock 2008, IDX Statistic 2008, Indonesia Stck Exchange, Jakarta

Exchange, Indonesia Stock 2009, IDX Statistic 2009, Indonesia Stck Exchange, Jakarta

Exchange, Indonesia Stock 2010, IDX Statistic 2010, Indonesia Stck Exchange, Jakarta

Exchange, Indonesia Stock 2011, IDX Statistic 2011, Indonesia Stck Exchange, Jakarta

Exchange, Indonesia Stock 2012, IDX Statistic 2012, Indonesia Stck Exchange, Jakarta

Exchange, Indonesia Stock 2013, IDX Statistic 2013, Indonesia Stck Exchange, Jakarta

Fabozzy, Frank. 2000. Bond Markets, Analysis and Strategies. Prentice Hall International.Inc. Fourth Edition. New Jersey.

Fabozzy, Frank. 1996. Bond Portfolio Management, New hope, Pensilvania, Frank J. Fabozzy Associates

Ghozali. Imam.2006, Analisis Multivarian dengan Program SPSS. Badan Penerbit Universitas Diponegoro. Semarang.

Harjito, Agus D, 2012, Manajemen Keuangan, Edisi kedua, Ekonisia, Yogyakarta

Hutajulu, 2008, Pengaruh Fundamental Enonomi dan Perusahaan Terhadap Imbal Hasil Obligasi Perusahaan Terbuka di Bursa Efek Indonesia, Tesis, Sekolah Pascasarjana Universitas Sumatra Utara, Medan

Kamstra, Mark., Peter Kennedy, and Teck-Kin Suan, 2001, Combining Bond Rating Forecasts Using Logit, The Financial Review, May, pp75-96

Manurung Adler, Desmon, Wilson. 2007. Hubungan Rasio-rasio Keuangandengan Rating Obligasi. Institute Perbanas. Jakarta

Sarwono, Jonathan , 2006, Metodologi Penelitian Kuantitatif dan Kualitatif, edisi I, Graha Ilmu, Yogyakarta

Sugiyono, 2009, Metode Penelitian Kuantitatif Kualitatif dan R\&D, edisi ke 8, Alfabeta, Bandung

Subramanyan \& John J.Wild, Analisa Laporan Keuangan, buku 1, edisi ke10, Salemba Empat, Jakarta

Subramanyan \& John J.Wild, Analisa Laporan Keuangan, buku 2, edisi ke10, Salemba Empat, Jakarta

Jonathan, Sarwono. 2006. Metode Penelitian Kuantitatif dan Kualitatif. Yogyakarta, Graha IImu 
Weston, J Fred and Eugene F. Brigham. 1990. Dasar-dasar Manqjemen Keuangan.

Edisi ke sembilan, Pcnerbit Eriangga. Jakarta.

Zubir, Zalmi, 2012, Portfolio Obligasi, edisi I,, Salemba empat, Jakarta

\section{Jurnal:}

Elfithasari. 2008. Analisis Pengaruh Faktor Fundamental Ekonomi terhadap Indeks Harga Obligasi Perusahaan. Tesis Sekolah Pascasarjana Universitas Sumatera Utara. Medan.

Gerry Lomi, Ronald, 2012, Analisis Pengaruh Inflasi, Harga Minyak dan Investment Grade terhadap harga saham di Index Bisnis 27 Periods 2009 - 2011, Lontar UI, Jakarta

Hutajulu.Maju. 2008. Pengaruh Faktor Fundamental Ekonomi dan Perusahaan terhadap Imbal Hasil Obligasi Perusahaan Terbuka di Bursa Efek Indonesia. Tesis Sekolah Pascasarjana Universitas Sumatera Utara. Medan.

Idris, Akmal, 2009, Penentuan Harga Obligasi Untuk Beberapa Nilai Parameter, FMIPA Matematika, Institut Pertanian Bogor, Bogor

Levi. 2001. Pengaruh Obligasi dan Diversijikasi Portofolio Internasional pada Bursa Efek Jakarta. Universitas Kristen Petra. Surabaya.

Kwantoro. Kwan Indrawati. 2003. Pengaruh Quick Ratio, EBIT per Total Debt, ROE, DER, Debt dan Durasi terhadap Return Obligasi Korporasi Indonesia. Universitas Kristen Petra. Surabaya.

Lubis, Richard Noviandi. 2009. Analisis Pengaruh Nilai Kurs, Suku Bunga Deposito, dan GDP terhadap Permintaan Obligasi Swasta di Indonesia. Tesis Sekolah Pascasarjana Universitas Sumatera Utara. Medan.

Meitasari.Yasmine dan Emelia.2007. Analisis Pengaruh Suku Bunga dan Rasio-Rasio Keuangan terhadap Return Obligasi Korporasi. Universitas Kristen Petra. Surabaya.

Nardi Sunardi (2017) Determinan Kebijakan Utang Serta Implikasinya terhadap Kinerja Perusahaan (Perusahaan yang tergabung dalam indeks LQ.45 yang terdaftar di Bursa Efek Indonesia Tahun 2011- 2015) Jurnal Sekuritas, Vol. 1, No.1 / September 2017 Universitas Pamulang.

Nardi Sunardi, Aceng Abdul Hamid, Lativa, Abdul Kadim, Natanael Tulus (2018) Determinant Of Cost Efficiency And It's Implications For Companies Performance Incorporated In The Lq.45 Index Listing In Idx For The Period of 2011-2016, International Journal of Applied Business and Economic Research,.Volume 16, Number 1, 2018, ISSN : 0972-7302

Puspitasari, Yeni. 2007. Pengaruh Kinerja Keuangan terhadap Harga Obligasi (Studi pada Perusahaan Manufaktur yang Tercatat di Bursa Efek Surabaya). Fakultas Ekonomi Universitas Muhammadiyah Malang. Malang.

Sen, Jung, (2010), Pengaruh Faktor Fundamental Ekonomi dan Perusahaan Terhadap Harga Obligasi Perusahaan Swasta di Bursa Efek Jakarta, Sekolah Pascasarjana Universitas Sumatera Utama, Medan 